RUTMech, t. XXXIII, z. 88 (4/16), październik-grudzień 2016, s. 361-369

\author{
Maria TYCHANICZ ${ }^{1}$ \\ Joanna WILK ${ }^{2}$ \\ Sebastian GROSICKI ${ }^{3}$
}

\title{
COMPARABLE ANALYSIS OF AN INVESTIGATION OF BIOMASS ENERGETIC PROPERTIES
}

\begin{abstract}
This paper presents the comparable analysis of the investigation of energetic properties of two types of biomass. The research was made on the manual and semi-automatic oxygen-bomb calorimeter KL-12Mn. The basic energetic properties include calorific value and heating value. Calculations were made according to the PN-ISO 1928 standard. The research was made for basket willow and paulownia tomentosa samples. To determine the average value of each parameter samples of each kind of biomass were researched three times on both devices, which increased the accuracy of methods. The paper also includes the uncertainty analysis.
\end{abstract}

Keywords: biomass, calorific value, bomb calorimeter, energetic properties, basket willow, paulownia tomentosa

\section{Introduction}

Biomass fuels represent the main group of renewable sources of energy, both in Poland and the European Union. Prevalent role in this group represents solid biomass, which is considered to be the ecologically clean alternative for coal. This group also includes forest, wood and agronomic waste products. There are many benefits connected with biomass utilization. It concerns mostly ecological issues due to no $\mathrm{CO}_{2}$ emissions connected with combustion of biomass. It should be marked that biomass is one of the cheapest and commonly available source of renewable energy. To popularize this method of generating heat power the possibility of combining biomass and coal to combust in traditional power plants should be mentioned. However home market of biomass is more diversified. This may result from the inappropriate quality

1 Autor do korespondencji/corresponding author: Maria Tychanicz, Politechnika Rzeszowska, 35-959 Rzeszów, al. Powst. Warszawy 12, tel. (17) 743-2299, e-mail: mtychanicz@prz.edu.pl

2 Joanna Wilk, Politechnika Rzeszowska, e-mail: joanwilk@prz.edu.pl

${ }^{3}$ Sebastian Grosicki, Politechnika Rzeszowska, e-mail: sebogr@prz.edu.pl 
of received material and its seasonal availability. Considering that, the idea of energetic plants cultivation seems to be the optimal solution for this problem. Energetic plants include special types of perennial plants, which are characterized by very fast annual weight growth. Their additional advantage includes cultivation of exhausted soils, which is in fact the method of improving the soil condition by supplying organic substances. Nowadays, beneficial energetic properties cause that the energetic plants become more popular in energy industry. The basic criteria concerning the evaluation of energetic properties of all kinds of fuels are calorific and heating values. The paper presents the results of the experimental investigation of calorific and heating values of two kinds of energetic plants. The analysis was made for chips of basket willow, which is the most popular and widely used energetic plant, because of its beneficial features. The other type of biomass are lops of paulownia tomento$s a$, which recently have become the subject of study in energetic applications. Over recent years this plant was used in furniture industry and gardening. But now it is also used as energetic plant due to comparable properties with typical energetic plants, i.e. basket willow. Research of all samples were made on manual and semi-automatic bomb calorimeter. Basic principle of operation of both devices is similar. Also, the method of the preparation of the fuel sample and the bomb before measurements is the same [1]. Properties of investigated fuel both calorific and heating values are calculated on the basis of the test results. The temperature is measured with a precise mercury thermometer with accuracy of $0.01^{\circ} \mathrm{C}$. For semi-automatic calorimeter, the calorific value is calculated automatically when the measurements are finished. The result is displayed in the dialog box of the program. Temperature measurement is realized also by control program. This eliminates any external influence on the process and the possibility of its potential correction. Any deviations from the assumed conditions are automatically signaled and displayed on the computer screen, but without giving any information about its origin. Also, the specifications of temperature sensors are unknown. Consequently, it can be noticed that both methods differentiate the way of temperature measurement and the way of obtaining results. So, the necessity of results verification and its repeatability is required. Each of fuel sample was tested three times. The method of obtaining of the calorific value was based on PN-ISO 1928 standard. Calculations of the heating value were made for general elementary content of wood biomass because of the impossibility of the basic elements content determination. Because of research limitations it was assumed that the percentage content of elementary matter is compatible with theoretical values. The summary contains the comparison of the results obtained from both devices. The uncertainty analysis was made for manual research results. Determination of the measurements uncertainty for semi-automatic method was impossible. 


\section{Calorimetric method of determining the energetic properties of solid fuels}

The aim of the investigation of the energetic properties of fuels during calorimetric method is burning the fuel sample in a bomb calorimeter filled with compressed oxygen and then measuring an increase of the temperature of water inside the calorimetric vessel. The calorific value is the quantity of heat which is released during the process of combustion of complete unit mass of solid fuel in the presence of oxygen. It is assumed that the end-gas products of the reaction are oxygen, nitrogen, carbon dioxide, sulfur dioxide, and water formed by the reaction of hydrogen and oxygen contained in the fuel sample are not condensed. The heating value is described analogically as the calorific value, except that water contained in exhaust gases and in the fuel sample before combustion, is completely condensed. The heating value of the fuel is quantitatively smaller than its calorific value. The difference represents the heat of water vapor condensation. The calculations of the calorific value are based on the thermal balance method. Assuming that the process is nonadiabatic the general equation describing the calorific value of fuels is in the form [2]:

$$
W_{g}^{a}=\frac{K \cdot\left[\left(T_{1}-T\right)-k_{1}\right]-k_{2}}{m}
$$

where: $W_{g}^{a}$ - the calorific value in analytical state $\mathrm{J} / \mathrm{kg}$,

$K$ - calorimeter heat storage capacity, $\mathrm{J} / \mathrm{K}$,

$T$ - the last reading of temperature in initial state, $\mathrm{K}$,

$T_{1}$ - the last reading of temperature in main state, $\mathrm{K}$,

$k_{1}$ - heat transfer correction, $\mathrm{K}$,

$k_{2}$ - additional thermal effects correction, $\mathrm{J}$

$m$ - fuel sample weight, $\mathrm{kg}$.

For semi-automatic calorimeter, the calorific value is calculated by using the following formula [3]:

$$
Q_{s}=\frac{C \cdot\left(D_{t}-k\right)-c}{m}
$$

where: $Q_{s}$ - the calorific value, $\mathrm{J} / \mathrm{g}$,

$C$ - calorimeter heat storage capacity, $\mathrm{J} /{ }^{\circ} \mathrm{C}$,

$D_{t}$ - general temperature rise during main period, ${ }^{\circ} \mathrm{C}$,

$k=0,5 \cdot\left[0,2 \cdot\left(T_{2}-T_{1}\right)+0,2 \cdot\left(T_{4}-T_{3}\right)\right]+0,2 \cdot(n-1) \cdot\left(T_{4}-T_{3}\right)$ - heat transfer correction, $\mathrm{K}$,

$c$ - the sum of additional thermal effects correction, $\mathrm{J}$, 
Calculations of the heating value require elemental analysis of the fuel, especially the hydrogen content in the fuel sample and its total moisture content. For fuel samples in operating state the heating value during manual research is described as follows:

$$
W_{d}^{r}=W_{g}^{r}-2453,5 \cdot\left(8,84 \cdot h^{r}+w_{c}^{r}\right)
$$

where: $W_{d}^{r}-$ the heating value in operating state, $\mathrm{J} / \mathrm{kg}$,

$W_{g}^{r}$ - the calorific value in operating state, $\mathrm{J} / \mathrm{kg}$,

$h^{r}$ - weight concentration of hydrogen in fuel sample, $\%$,

$w_{c}^{r}-$ total moisture content, $\%$.

Calculations of the heating value for fuel sample in operating state during semi-automatic method is accomplished in the control program, where the fuel's physicochemical properties should be entered in proper columns. The heating value can be calculated by using the formula:

$$
Q_{i r}=\frac{100-W_{t}}{100-W_{a}} \cdot\left(Q_{i a}+P\left(W_{a}\right)\right)-P\left(W_{t}\right)
$$

where: $W_{t}-$ total moisture content, $\%$,

$W_{a}$ - percentage moisture content in analytical fuel sample, $\%$,

$Q_{i a}$ - the heating value in analytical state, $\mathrm{J} / \mathrm{kg}$,

$P$ - water heat of evaporation in $25^{\circ} \mathrm{C}, \mathrm{J} / \mathrm{g}$.

Heat storage capacity of the calorimeter must be assigned every time before using it for further research. Heat capacity is obtained by burning the calorimeter standard (commonly benzoic acid is used). Then the transformation of equation (1) with respect to $K$ allows the calculations of calorimeter's heat capacity. The conditions under which the testing of heat capacity take place must be maintained during each measurement.

\section{Experimental stand for manual and semi-automatic calori- metric research}

Figure 1 presents the semi-automatic test station which is used in the Department of Thermodynamics and Fluid Mechanics at the Rzeszow University of Technology. The real view of the bomb calorimeter is shown in Figure 2 [1]. General calorimetric setup consists of the outer jacket of the calorimeter, thermally isolated calorimetric vessel and bomb calorimeter immersed in the vessel. All components are arranged concentrically to minimize thermal effects. Mechanical mixer provides the temperature uniformity. One of the most crucial stage during pre-operating procedures is the proper fuel sample preparation which depends on the fuel's state of aggregation. 


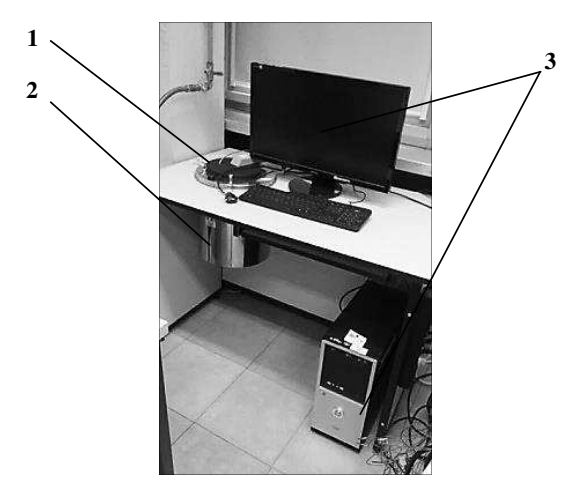

Fig. 1. Semi- automatic bomb calorimeter: 1 - calorimeter's envelope, 2 - bomb calorimeter's outer jacket, 3 - data acquisition system

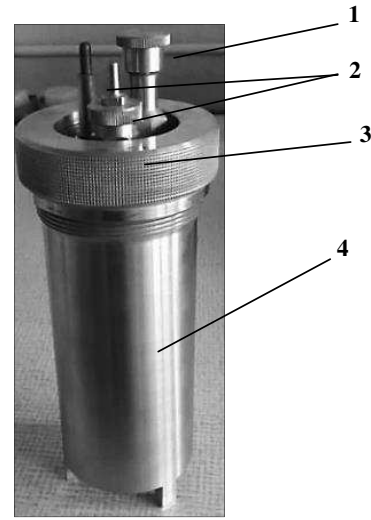

Fig. 2. Bomb calorimeter: 1 - screw plug, 2 - electrodes, 3 - nut, 4 - measuring vessel

Preparation of biomass fuel samples should be done directly before measurements. Previously prepared samples should be stored in the pressure-tight container. As far as the solid biomass is concerned it should be disintegrated first. Fuel weight should be with a range of 0.8-1.2 $\mathrm{g}$ and this amount should be equal during each subsequent measurement. This guarantees the temperature rise of 1.8-3.0 K. Next the fuel sample is pressed to a form of a pellet in the hand press. The whorled middle part of $10 \mathrm{~cm}$ resistance wire is located inside the pellet before pressing. The pellet with the wire as well as the wire itself should be weighed on analytical balance. Then the prepared sample is attached to electrodes inside bomb's head by clinching the prominent ends of the wire with contracting collets. Afterwards, the bomb is filled with compressed oxygen. Calorimetric vessel should be filled in with water. The amount of water should be about $2700 \mathrm{~cm}^{3}$. This amount ensures that the electrode in the bomb's head can slightly stick out above the water surface. This allows the connection between electrode and ignition wires. Next, the calorimeter jackets can be closed and the mixer can be activated. When the thermal conditions become stable, the ignition of the sample can be started and temperature of water in the vessel should be detected. As far as the semiautomatic calorimeter is concerned, preparation of the bomb and fuel sample proceeds analogically. The measurement process itself is based on the registration of the representative temperature of the thermal balance, which are next converted into the numerical form. The relation between the variation of temperature with time is presented graphically in a form of a diagram, which is displayed in the dialog box in the duration of the experiment. Data acquisition system determines itself the moment of reading the temperature difference as well as the moment of ignition and the measurements completeness. The calorific value is then calculated by using the proper application icon. 


\section{Calculation results}

The fuel samples were weighed on the laboratory balance with the accuracy of $10^{-6} \mathrm{~g}$. Moisture content was prescribed by means of electronic laboratory moisture analyzer. Due to the lack of possibilities in determining the elemental analysis of researched fuels required for heating value calculations the elementary content of wood biomass was used (Table 1). The uncertainty limits were obtained using the exact differential method. The results of measurements of weight and moisture content for willow samples are presented in Table 2. The calculations results are presented in sequence in Tables 3-7. Table 3 and Table 4 contain the comparison of manual and semi-automatic research results. The results of measurements of weight and moisture content for paulownia tomentosa samples are presented in Table 5. Tables 6 and 7 contain the comparison of manual and semi-automatic research results.

Table 1. Elementary content of wood biomass [4]

\begin{tabular}{|c|c|c|c|c|}
\hline \multicolumn{5}{|c|}{ Elementary content of matter, \% d.m } \\
\hline carbon & hydrogen & oxygen & nitrogen & sulphur \\
\hline 48.15 & 5.87 & 44.75 & 0.03 & 0.00 \\
\hline \multicolumn{5}{|c|}{ Approximated content of dry matter, \% d.m } \\
\hline \multicolumn{4}{|c|}{ combined carbon } & \multicolumn{3}{|c|}{ volile matter } & ash \\
\hline \multicolumn{3}{|c|}{81.02} & 1.20 \\
\hline
\end{tabular}

Table 2. Weight of willow samples and its relative humidity

\begin{tabular}{|c|c|c|}
\hline $\begin{array}{c}\text { Fuel sample mass in manual } \\
\text { measurements } \\
\cdot 10^{-3} \mathrm{~kg}\end{array}$ & $\begin{array}{c}\text { Fuel sample mass in semi- } \\
\text { automatic measurements } \\
\cdot 10^{-3} \mathrm{~kg}\end{array}$ & $\begin{array}{c}\text { Relative } \\
\text { humidity } \\
\%\end{array}$ \\
\hline 1.26768 & 1.3669 & \multirow{2}{*}{6.62} \\
\hline 1.30686 & 1.3514 & \\
\hline 1.38276 & 1.2981 & \\
\hline
\end{tabular}

Table 3. Comparison of research results of calorific value for basket willow

\begin{tabular}{|c|c|c|}
\hline Number of trial & $\begin{array}{c}\text { Calorific value obtained during } \\
\text { manual measurements } \\
\mathrm{kJ} / \mathrm{kg}\end{array}$ & $\begin{array}{c}\text { Calorific value obtained during } \\
\text { semi-automatic measurements } \\
\mathrm{kJ} / \mathrm{kg}\end{array}$ \\
\hline 1 & $16021 \pm 204$ & 18302 \\
\hline 2 & $15227 \pm 198$ & 18633 \\
\hline 3 & $17337 \pm 187$ & 17626 \\
\hline Mean value & $\mathbf{1 6 1 9 5}$ & $\mathbf{1 8 1 8 7}$ \\
\hline $\begin{array}{l}\text { Standard deviation of } \\
\text { mean }\end{array}$ & 615 & 280.5 \\
\hline
\end{tabular}


Table 4. Comparison of research results of heating value for basket willow

\begin{tabular}{|c|c|c|}
\hline Number of trial & $\begin{array}{c}\text { Heating value obtained during } \\
\text { manual measurements } \\
\mathrm{kJ} / \mathrm{kg}\end{array}$ & $\begin{array}{c}\text { Heating value obtained during } \\
\text { semi-automatic measurements } \\
\mathrm{kJ} / \mathrm{kg}\end{array}$ \\
\hline 1 & 13525 & 16980 \\
\hline 2 & 12784 & 17310 \\
\hline 3 & 14754 & 16300 \\
\hline Mean value & $\mathbf{1 3 6 8 7}$ & $\mathbf{1 6 8 6 3}$ \\
\hline
\end{tabular}

Table 5. Weight of paulownia tomentosa samples and its relative humidity

\begin{tabular}{|c|c|c|}
\hline $\begin{array}{c}\text { Fuel sample mass in } \\
\text { manual measurements } \\
\cdot 10^{-3} \mathrm{~kg}\end{array}$ & $\begin{array}{c}\text { Fuel sample mass in semi- } \\
\text { automatic measurements } \\
\cdot 10^{-3} \mathrm{~kg}\end{array}$ & $\begin{array}{c}\text { Relative humidity } \\
\text { of fuel sample } \\
\%\end{array}$ \\
\hline 1.29283 & 1.3170 & \multirow{2}{*}{6.91} \\
\hline 1.36382 & 1.3200 & \\
\hline 1.39227 & 1.2626 & \\
\hline
\end{tabular}

Table 6. Comparison of research results of calorific value for paulownia tomentosa

\begin{tabular}{|c|c|c|}
\hline Number of trial & $\begin{array}{c}\text { Calorific value obtained during } \\
\text { manual measurements } \\
\mathrm{kJ} / \mathrm{kg}\end{array}$ & $\begin{array}{c}\text { Calorific value obtained during } \\
\text { semi-automatic measurements } \\
\mathrm{kJ} / \mathrm{kg}\end{array}$ \\
\hline 1 & $16900 \pm 200$ & 18523 \\
\hline 2 & $17231 \pm 190$ & 18268 \\
\hline 3 & $16063 \pm 186$ & 18533 \\
\hline Mean value & $\mathbf{1 6 7 3 1}$ & $\mathbf{1 8 4 4 1}$ \\
\hline Standard deviation of mean & 348 & 87 \\
\hline
\end{tabular}

Table 7. Comparison of research results of heating value for paulownia tomentosa

\begin{tabular}{|c|c|c|}
\hline Number of trial & $\begin{array}{c}\text { Heating value obtained during } \\
\text { manual measurements } \\
\mathrm{kJ} / \mathrm{kg}\end{array}$ & $\begin{array}{c}\text { Heating value obtained during } \\
\text { semi-automatic measurements } \\
\mathrm{kJ} / \mathrm{kg}\end{array}$ \\
\hline 1 & 14290 & 17189 \\
\hline 2 & 14598 & 16934 \\
\hline 3 & 13510 & 17196 \\
\hline Mean value & $\mathbf{1 4 1 3 3}$ & $\mathbf{1 7 1 0 6}$ \\
\hline
\end{tabular}

\section{Summary}

The aim of this study was the comparable analysis of energetic properties of basket willow and paulownia tomentosa samples. Measurements were performed on manual and semi- automatic bomb calorimeter. For basket willow and paulownia tomentosa samples the average heating values obtained during manual and semi-automatic measurements are respectively: $13687 \mathrm{~kJ} / \mathrm{kg}$, $16863 \mathrm{~kJ} / \mathrm{kg}, 14133 \mathrm{~kJ} / \mathrm{kg}$ and $17106 \mathrm{~kJ} / \mathrm{kg}$. The percentage difference between the results obtained from both devices is about $10 \%$. Received results are classical values for solid biomass and they show certain repeatability, 
however there are some differences which may suggest the overstatement of the results obtained from semi- automatic calorimeter or understatement resulting from manual calculations. Due to similar humidity of both researched plants, the difference is mostly connected with measuring method. The calorimetric method is susceptible to following errors:

- the variation of ambient temperature and instability of thermal conditions, which increase the non-adiabatic character of the process,

- too high temperature difference between outer jacket and calorimetric vessel, too late ignition of fuel sample or its incomplete combustion,

- differences in tested fuel samples mass,

- the lack of elemental analysis of fuel samples and the fact of not including the effect of creation the nitric acid and sulfuric acid.

Errors arising during the calorimetric measurements are mostly connected with human fault. This effect is observable in manual research. Reading temperature from mercury thermometer is the potential source of errors in manual measurements. However, this effect can be easily corrected, i.e. by adapting magnifier. It can be assumed that the reduction of human sources of errors would improve the accuracy of the manual calorimetric method. As far as the semi-automatic calorimeter is concerned, the estimation of potential sources of errors is unknown because of the lack of information of the temperature sensors types and its specifications. Therefore, it can be stated that despite the reducing human factors the measurement accuracy will not be improved significantly. It is caused by the computational control of the process and the lack of human influence within the process.

Despite the presence of many factors affecting the accuracy of the process, the calorimetric method is classified as one of the most accurate and precise method in thermal engineering.

\section{References}

[1] Tychanicz M.: Badania właściwości energetycznych paliw stałych - analiza porównawcza wyników pomiarów ręcznych i półautomatycznych, praca magisterska, Rzeszów 2015.

[2] Norma PN-ISO 1928: Paliwa stałe. Wyznaczanie ciepła spalania metodą spalenia w bombie kalorymetrycznej i obliczenie wartości opałowej.

[3] Instrukcja obsługi kalorymetru KL-12Mn, PRECYZJA-BIT.

[4] Wandrasz J.W., Wandrasz A.J.: Paliwa formowane- biopaliwa i paliwa z odpadów w procesach termicznych, Wyd. Seidel-Przywecki Sp. z o.o., Warszawa 2006. 


\section{ANALIZA PORÓWNAWCZA BADAŃ WŁAŚCIWOŚCI \\ ENERGETYCZNYCH BIOMASY}

\section{Streszczenie}

W pracy zawarto analizę porównawczą właściwości energetycznych dwóch rodzajów biomasy stałej, wyznaczonych przy pomocy kalorymetru ręcznego oraz półautomatycznego KL-12Mn. Do podstawowych właściwości paliw stałych, które zostały wyznaczone, należą ciepło spalania i wartość opałowa, których obliczenia zostały przeprowadzone zgodnie z normą PN-ISO 1928. Analizie poddano próbki wierzby energetycznej oraz paulowni puszystej. Próbka każdego z paliw została poddawana trzykrotnym pomiarom, zarówno w urządzeniu ręcznym, jak i półautomatycznym, dzięki czemu można było wyznaczyć średnią wartość każdego z parametrów Analizę uzupełniono o rachunek niepewności pomiarowych.

Słowa kluczowe: biomasa, wartość opałowa, bomba kalorymetryczna, właściwości energetyczne, wierzba energetyczna, paulownia tomentosa

DOI: $10.7862 / \mathrm{rm} .2016 .29$

Otrzymano/received: 10.09.2016 r.

Zaakceptowano/accepted: $24.10 .2016 r$. 